\title{
ANALISIS EFEK BUKAAN PADA WAFFLE SLAB DENGAN METODE ELEMEN HINGGA
}

\author{
Raynaldo Feryanto ${ }^{1}$ dan Leo S. Tedianto ${ }^{2}$ \\ ${ }^{1}$ Program Studi Sarjana Teknik Sipil, Universitas Tarumanagara, Jl. Letjen S. Parman No.1 Jakarta \\ Email: raynaldoferyanto@gmail.com \\ ${ }^{2}$ Program Studi Sarjana Teknik Sipil, Universitas Tarumanagara, Jl. Letjen S. Parman No.1 Jakarta \\ Email: leotedi@gmail.com
}

\begin{abstract}
ABSTRAK
Pelat dengan balok pendukung berupa balok grid atau balok 2 arah yang saling tegak lurus dikenal dengan nama Waffle Slab. Waffle Slab biasa digunakan untuk bangunan yang tidak memakai kolom di tengah-tengah bentangnya seperti ruang auditorium. Tujuan dari skripsi ini adalah untuk meninjau apa efek dari adanya bukaan pada waffle slab dengan metode elemen hingga dengan memvariasikan ukuran dan posisi dari bukaan tersebut dan juga untuk mengetahui efek pemakaian stiffening ribs disekitar bukaan. Dari hasil analisis dapat disimpulkan bahwa terjadinya peningkatan konsentrasi tegangan lentur di sekitar bukaan yang mencapai lebih dari dua kali lipat dibandingkan tegangan lentur sebelum adanya bukaan. bukaan yang diletakkan pada bagian sudut dari pelat memberikan efek yang paling signifikan berupa peningkatan konsentrasi tegangan lentur yang paling besar. Selanjutnya besar tengangan lentur, lendutan, tegangan geser pons, dan momen lentur berbanding lurus dengan besarnya ukuran dari bukaan. Penggunaan stiffening ribs di sekitar bukaan memberikan pengaruh yang sangat signifikan terhadap berkurangnya konsentrasi tegangan lentur yang terjadi di sekitar bukaan dan besarnya lendutan yang terjadi pada pelat.
\end{abstract}

Kata kunci: Waffle slab, bukaan, konsentrasi tegangan, stiffening ribs

\section{PENDAHULUAN}

Bangunan gedung bertingkat memiliki beberapa komponen yang dianggap sebagai komponen struktur, salah satu komponen tersebut adalah pelat lantai. Seiring perkembangan zaman, pelat lantai juga mengalami perkembangan dimana yang pada awalnya hanya pelat konvensional. Sekarang ini ada berbagai macam pelat lantai, diantranya yang lazim digunakan adalah flat slab, ribbed slab, dan waffle slab. Masing-masing sistem pelat ini memiliki kelebihan dan kekurangan tersendiri. Pemilihan pelat ini dapat disesuaikan dengan tujuan dan fungsi dari struktur yang diinginkan. Pada bangunan yang membutuhkan jarak antar kolom yang besar seperti auditorum, stadium dan beberapa bangunan lainnya salah satu solusinya adalah menggunakan sistem waffle slab. Waffle slab merupakan sistem pelat dengan balok pendukungnya berupa balok grid atau dengan balok 2 arah dimana balok-balok tersebut saling tegak lurus. Sistem pelat waffle Slab memiliki beberapa keuntungan, diantaranya adalah mempunyai kekakuan yang besar dan tebal pelat yang tipis (Puspantoro \& Benny,1993). Selain itu penggunaan sistem waffle slab juga dapat mempengaruhi tata letak kolom, dikarenakan semakin kecilnya lendutan pada balok dapat membuat jarak antar kolom pada portal bisa lebih besar daripada pada menggunakan pelat konvensional. Umumnya panjang bentang bisa mencapai sekitar 10 meter.

Waffle slab biasa juga dipakai untuk kepentingan arsitektural pada ruangan berukuran besar. Penggunaan kolom pada bangunan seperti auditorium, stadium, dan ruang teater akan mengurangi utilitas dari bangunan tersebut seperti pencahayaan dan sudut pandang sehingga penggunaan waffle slab adalah pilihan yang tepat untuk digunakan. Pada waffle slab balok adalah komponen terpenting dimana balok menerima konstribusi beban yang paling besar dari keseluruhan beban yang diterima oleh pelat. Pelat lantai umumnya memiliki opening atau bukaan yang dibutuhkan untuk beberapa fungsi seperti untuk tangga, pendingin ruangan, dan juga elevator.

Bukaan pada pelat termasuk waffle slab dapat berdampak buruk bagi kekuatan dan kekakuan dari waffle slab. Pelemahan tersebut diakibatkan karena kurangnya jumlah dari beton dan baja yang dipakai untuk perkuatan Bukaan berukuran kecil pada pelat biasanya tidak perlu diberi perhatian lebih, tetapi jika ukuran bukaan tersebut berukuran besar maka harus diberi perhatian khusus karena dapat berdampak cukup besar terhadap kekuatan dan kekakuan dari pelat. Perhatian khusus yang dapat dilakukan ada berbagai cara, salah satunya adalah pemasangan stiffening ribs. Stiffening ribs merupakan sebuah komponen struktur yang dipasang atau ditambahkan pada suatu konstruksi yang memerlukan perkuatan atau pengaku tambahan. 
Pembahasan kali ini dilakukan untuk menyelidiki dan meneliti seberapa besar efek dari pemakaian stiffening ribs di sekitar bukaan dan tanpa pemakaian stiffening ribs di sekitar bukaan. Analisa akan dilakukan dengan peletakan bukaan di 5 posisi berbeda dan dengan 2 ukuran berbeda dan ditinjau terhadap besarnya tegangan lentur, lendutan, momen lentur, dan tegangan geser pons. Analisis akan dilakukan dengan menggunakan program berbasis Metode Elemen Hingga.

\section{DASAR TEORI WAFFLE SLAB}

Waffle slab merupakan sistem pelat dengan balok pendukungnya berupa balok grid atau dengan balok 2 arah dimana balok-balok tersebut saling tegak lurus bisa disebut juga sebagai konstruksi balok jois. Sistem pelat waffle Slab memiliki beberapa keuntungan, diantaranya adalah mempunyai kekakuan yang besar dan tebal pelat yang tipis (Puspantoro \& Benny,1993). Untuk bentang pelat yang panjang dan relatif memikul beban hidup yang ringan sistem waffle slab dapat di desain dengan konstruksi balok jois (Wight, 2016). Menurut SNI 2847:2013, konstruksi balok jois terdiri dari kombinasi monolit rusuk berspasi beraturan dan slab diatasnya yang disusun untuk membentang dalam satu arah atau dua arah ortogonal. Ketentuan dalam menentukan jarak antar rusuk dan dimensi rusuk adalah sebagai berikut:

1. Lebar rusuk tidak boleh kurang dari $100 \mathrm{~mm}$,

2. Tinggi rusuk tidak lebih dari 31/2 kali lebar minimum badannya,

3. Spasi bersih antar rusuk tidak boleh melebihi $750 \mathrm{~mm}$.

4. Konstruksi balok jois yang tidak memenuhi batasan di atas harus dirancang sebagai slab dan balok.

Bukaan dengan segala ukuran diizinkan pada sistem slab bila ditunjukkan oleh analisis bahwa kekuatan desain paling sedikit sama dengan kekuatan perlu yang ditetapkan pada SNI 2847-2013 pasal 9.2 mengenai kekuatan perlu dan 9.3 kekuatan desain, dan bahwa semua kondisi kemampuan layan, termasuk pembatasan pada lendutan, harus dipenuhi.

Sebagai alternatif untuk analisis yang disyaratkan oleh pernyataan diatas, bukaan diizinkan hanya pada sistem slab, sesuai dengan poin poin berikut ini.

1. Bukaan dengan segala ukuran diizinkan pada daerah bersama pada perpotongan lajur-lajur tengah, asalkan jumlah total tulangan perlu untuk panel tanpa bukaan dipertahankan.

2. Pada daerah bersama pada perpotongan lajur-lajur kolom, tidak lebih dari seperdelapan lebar lajur kolom dalam masing-masing bentang boleh dihentikan oleh bukaan. Jumlah tulangan ekivalen dengan yang dihentikan oleh bukaan harus ditambahkan pada sisi-sisi bukaan.

3. Pada daerah bersama untuk satu lajur kolom dan satu lajur tengah, tidak lebih dari seperempat tulangan dalam masing-masing lajur boleh dihentikan oleh bukaan. Jumlah tulangan ekivalen dengan yang dihentikan oleh bukaan harus ditambahkan pada sisi-sisi bukaan.

\section{METODE ELEMEN HINGGA}

Metode Elemen Hingga adalah metode numerik yang digunakan untuk memecahkan permasalahan dalam bidang rekayasa ataupun bidang fisik lainnya. Permasalahan-permasalahan dalam bidang rekayasa yang dapat dipecahkan dengan metode ini meliputi analisa struktur, analisa tegangan, perpindahan panas dan massa, dan medan elektromagnetik. Untuk masalah analisis struktur, penyelesaian yang didapat dari Metode Elemen Hingga adalah lendutan (displacement) pada setiap titik yang selanjutnya digunakan untuk mendapatkan nilai regangan (strain) dan tegangan (stress).

Prinsip dasar dari metode elemen hingga adalah untuk menemukan solusi dari suatu masalah yang rumit dengan menggantinya menjadi masalah yang lebih sederhana, karena kita mengganti masalah tersebut menjadi yang sesuatu yang lebih sederhana kita hanya dapat mendapatkan solusi yang mendekati bukan solusi exact. Metode matematis yang ada sekarang ini tidak dapat menemukan solusi exact (dan kadang kadang bahkan solusi yang mendekati) dari kebanyakan masalah praktikal yang ada. Oleh karena tidak ada yang dapat menyelesaikan masalah-masalah seperti itu, kita menggunakan metode elemen hingga untuk meyelesaikannya.

Dalam metode elemen hingga, suatu elemen dibagi menjadi beberapa elemen yang lebih kecil, yang mana elemenelemen tersebut saling berhubungan dengan elemen lainnya pada titik-titik simpul elemen atau dikenal dengan node. Proses pembagian ini disebut dengan diskritisasi.Perhitungan Metode Elemen Hingga merupakan perhitungan yang dilakukan secara berulang-ulang dari beberapa persamaan yang sama, sehingga penggunaan program dapat meningkatkan ketelitian dan juga kecepatan dalam menyelesaikan perhitungan tersebut. Teknologi komputer yang ada sekarang ini sudah sangat mampu untuk menunjang perhitungan dengan basis metode elemen hingga. Ini adalah alasan mengapa metode elemen hingga perkembangannya cukup pesat dewasa ini 


\section{STUDI KASUS}

Studi kasus dilakukan dengan memodelkan waffle slab pada program berbasis metode elemen hingga terhadap beban gravitasi pada panel pelat lantai dengan sistem Waffle Slab dengan empat buah kolom di keempat sudut dari pelat tersebut, dimana jarak antar kolom tersebut ialah $8 \mathrm{~m}$. dengan tinggi story $4 \mathrm{~m}$, f'c pelat $35 \mathrm{Mpa}$, f'c stiffening ribs $35 \mathrm{Mpa}$, f'c kolom $40 \mathrm{Mpa}$, SDL yang digunakan $150 \mathrm{~kg} / \mathrm{m}^{2}$, live load $479 \mathrm{~kg} / \mathrm{m}^{2}$, ukuran kolom $300 \mathrm{~mm} / 300 \mathrm{~mm}$ dan stiffening ribs 200 $\mathrm{mmx} 430 \mathrm{~mm}$. Untuk ukuran waffle slab dipakai lebar ribs (balok waffle slab) $100 \mathrm{~mm}$, tinggi ribs $350 \mathrm{~mm}$, jarak antar ribs $500 \mathrm{~mm}$, dan tebal pelat $80 \mathrm{~mm}$.

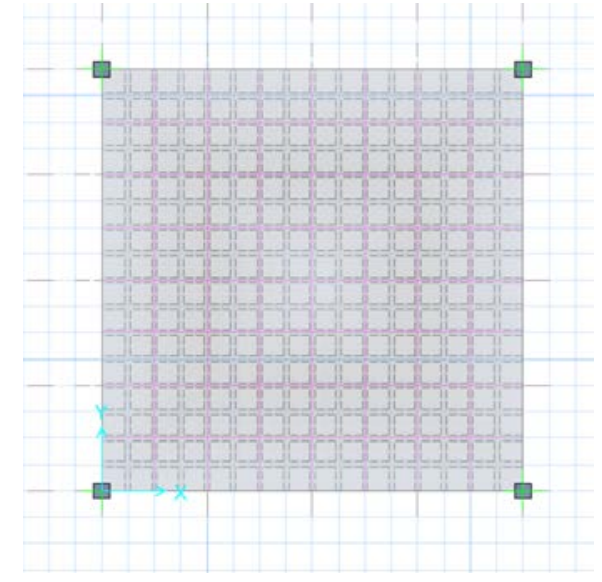

Gambar 1. Tampak atas dari kasus yang dimodelkan

Analisis akan dilakukan dengan 21 buah kasus. Pemodelan akan memvariasikan letak bukaan, ukuran bukaan dan penggunaan stiffening ribs.

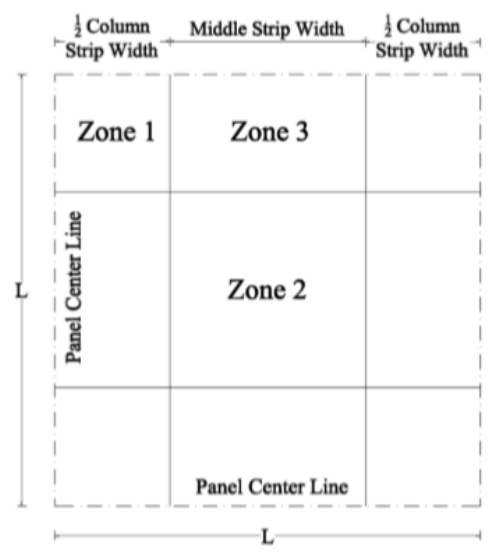

Gambar 2. Zona peletakkan bukaan

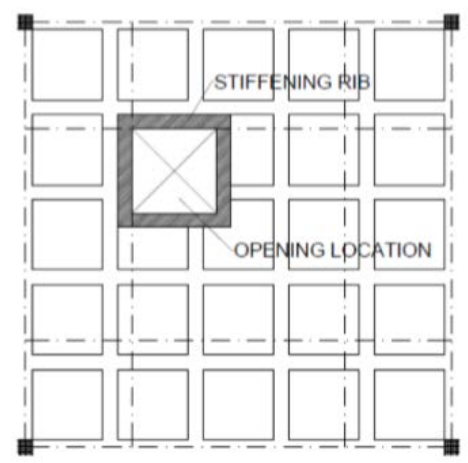

Gambar 3. Penggunaan stiffening ribs disekitar bukaan

Studi kasus memvariasikan ukuran bukaan yang digunakan, lokasi peletakkan bukaan dan penggunaan dan stiffening ribs. Dari variasi ke 3 variabel tersebut didapatkan jumlah studi kasus sebanyak 21 model kasus yang ditampilkan pada tabel dibawah ini: 
Tabel 1. Studi kasus

\begin{tabular}{|c|c|c|c|}
\hline No & Ukuran bukaan & Lokasi bukaan & Stiffening ribs \\
\hline 1 & - & - & - \\
\hline 2 & $500 \mathrm{mmx} 500 \mathrm{~mm}$ & zona 2 & - \\
\hline 3 & $500 \mathrm{~mm} \times 500 \mathrm{~mm}$ & zona 2 & $\mathrm{v}$ \\
\hline 4 & $500 \mathrm{mmx} 500 \mathrm{~mm}$ & antara zona 2 dan zona 3 & - \\
\hline 5 & $500 \mathrm{~mm} \times 500 \mathrm{~mm}$ & antara zona 2 dan zona 3 & $\mathrm{v}$ \\
\hline 6 & $500 \mathrm{~mm} \times 500 \mathrm{~mm}$ & zona 3 & - \\
\hline 7 & $500 \mathrm{~mm} \times 500 \mathrm{~mm}$ & zona 3 & $\mathrm{v}$ \\
\hline 8 & $500 \mathrm{mmx} 500 \mathrm{~mm}$ & antara zona 2 dan zona 1 & - \\
\hline 9 & $500 \mathrm{mmx} 500 \mathrm{~mm}$ & antara zona 2 dan zona 1 & $\mathrm{~V}$ \\
\hline 10 & $500 \mathrm{mmx} 500 \mathrm{~mm}$ & zona 1 & - \\
\hline 11 & $500 \mathrm{mmx} 500 \mathrm{~mm}$ & zona 1 & $\mathrm{~V}$ \\
\hline 12 & $1500 \mathrm{mmx} 1500 \mathrm{~mm}$ & zona 2 & - \\
\hline 13 & $1500 \mathrm{mmx} 1500 \mathrm{~mm}$ & zona 2 & $\mathrm{v}$ \\
\hline 14 & $1500 \mathrm{mmx} 1500 \mathrm{~mm}$ & antara zona 2 dan zona 3 & - \\
\hline 15 & $1500 \mathrm{mmx} 1500 \mathrm{~mm}$ & antara zona 2 dan zona 3 & $\mathrm{v}$ \\
\hline 16 & $1500 \mathrm{mmx} 1500 \mathrm{~mm}$ & zona 3 & - \\
\hline 17 & $1500 \mathrm{mmx} 1500 \mathrm{~mm}$ & zona 3 & $\mathrm{v}$ \\
\hline 18 & 1500mmx1500mm & antara zona 2 dan zona 1 & - \\
\hline 19 & $1500 \mathrm{mmx} 1500 \mathrm{~mm}$ & antara zona 2 dan zona 1 & $\mathrm{v}$ \\
\hline 20 & $1500 \mathrm{mmx} 1500 \mathrm{~mm}$ & zona 1 & - \\
\hline 21 & $1500 \mathrm{mmx} 1500 \mathrm{~mm}$ & zona 1 & $\mathrm{~V}$ \\
\hline
\end{tabular}

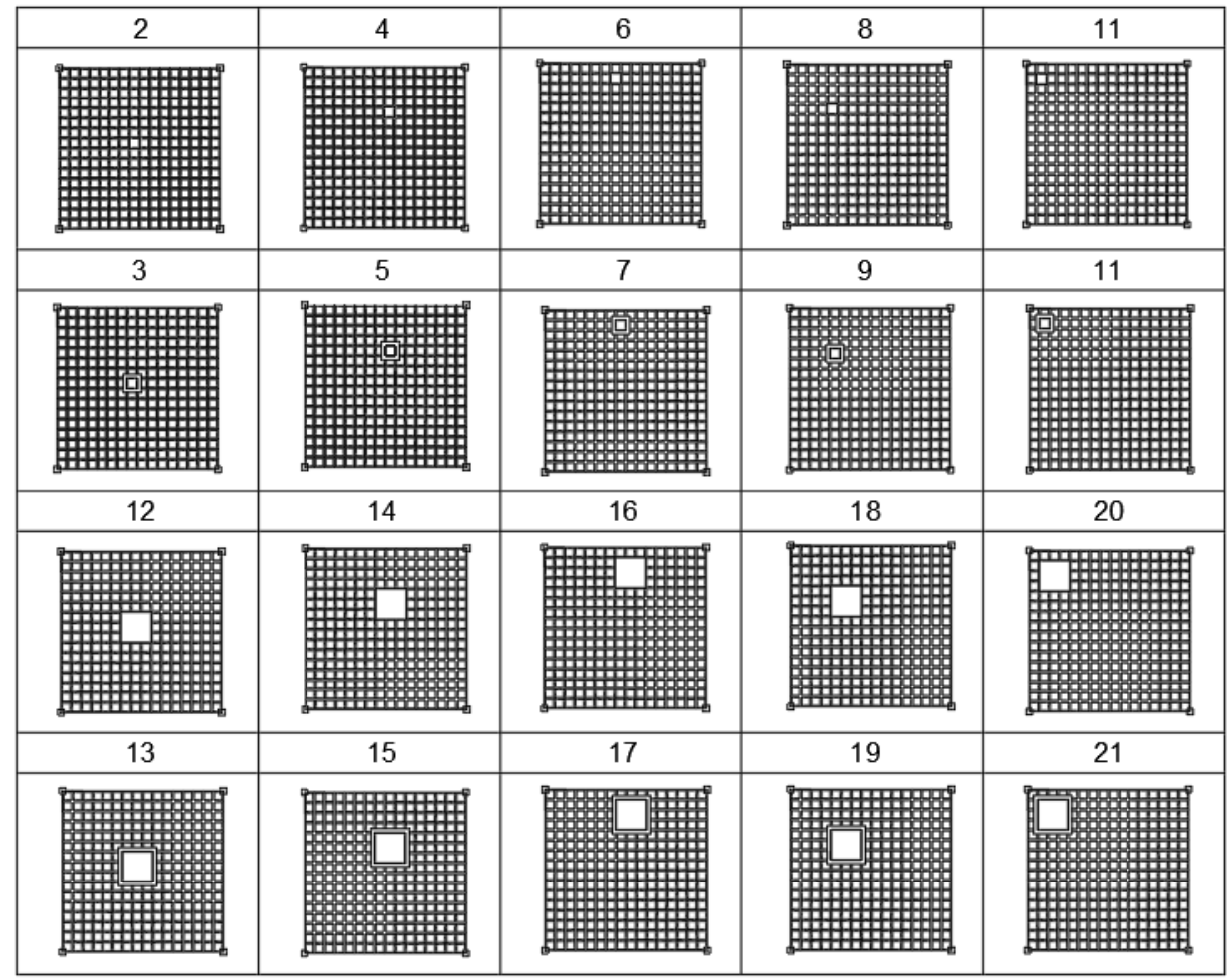

Gambar 4. Pemodelan dari Studi kasus 


\section{Hasil Analisis}

Analisis dilakukan terhadap besar lendutan pada tengah bentang, tegangan lentur disekitar bukaan, rasio tegangan geser pons banding tahanan geser, dan momen lentur sisi atas dan sisi bawah.

\section{Hasil Analisis Lendutan}

Hasil analisis lendutan pada tengah bentang dibandingkan dengan tanpa adanya bukaan ditampilkan pada tabel dan grafik di bawah ini:

Tabel 2. Besar lendutan di tengah bentang dari tiap kasus

\begin{tabular}{|c|c|c|}
\hline No. Kasus & Lendutan (mm) & \%beda \\
\hline 1 & $-17,9875$ & 0 \\
\hline 2 & $-18,103$ & 0,642113 \\
\hline 3 & $-18,0358$ & 0,26852 \\
\hline 4 & $-18,0575$ & 0,389159 \\
\hline 5 & $-18,0346$ & 0,261849 \\
\hline 6 & $-18,1903$ & 1,12745 \\
\hline 7 & $-18,0539$ & 0,369145 \\
\hline 8 & $-18,003$ & 0,086171 \\
\hline 9 & $-17,9995$ & 0,066713 \\
\hline 10 & $-18,2483$ & 1,449896 \\
\hline 11 & $-18,1041$ & 0,648228 \\
\hline 12 & $-18,2843$ & 1,650035 \\
\hline 13 & $-18,1317$ & 0,801668 \\
\hline 14 & $-18,1047$ & 0,651564 \\
\hline 15 & $-18,0449$ & 0,31911 \\
\hline 16 & $-19,1632$ & 6,536206 \\
\hline 17 & $-18,362$ & 2,082001 \\
\hline 18 & $-18,0794$ & 0,510688 \\
\hline 19 & $-18,0461$ & 0,325949 \\
\hline 20 & $-19,2918$ & 7,251147 \\
\hline 21 & $-18,4224$ & 2,41779 \\
\hline
\end{tabular}




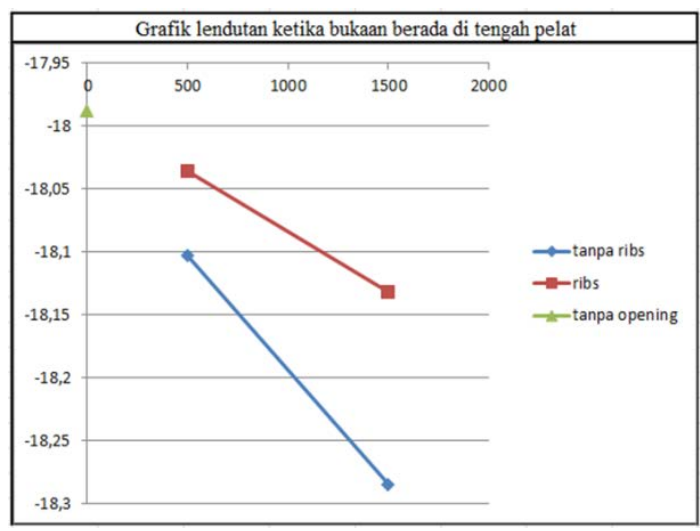

Gambar 5. Perbandingan lendutan ditengah bentang ketika bukaan berada di tengah pelat

Dari hasil diatas didapatkan bahwa lendutan semakin besar ketika adanya bukaan, lalu semakin besarnya bukaan tersebut semakin besar pula lendutan yang terjadi, posisi bukaan yang diletakkan pada sudut pelat memberikan lendutan yang paling besar dan penggunaan stiffening ribs dapat mengurangi besarnya lendutan tersebut.

\section{Hasil Analisis Tengangan Lentur}

Hasil analisis besarnya tengangan lentur di sekitar bukaan dibandingkan dengan tanpa adanya bukaan ditampilkan pada tabel dan grafik di bawah ini:

Tabel 3. Besar tegangan lentur di sekitar bukaan dari tiap kasus

\begin{tabular}{|c|c|c|c|}
\hline No. kasus & Tanpa bukaan & $\begin{array}{l}\text { Dengan } \\
\text { bukaan }\end{array}$ & $\begin{array}{c}\text { \%Perbandingan dengan tanpa } \\
\text { bukaan }\end{array}$ \\
\hline 2 & 0,8954 & 1,7124 & 191,2441 \\
\hline 3 & 0,8954 & 0,7789 & 86,9891 \\
\hline 4 & 2,9044 & 3,5216 & 121,2505 \\
\hline 5 & 2,9044 & 1,9811 & 68,2103 \\
\hline 6 & 6,8524 & 10,8642 & 158,5459 \\
\hline 7 & 6,8524 & 3,8478 & 56,1526 \\
\hline 8 & 2,1290 & 3,4725 & 163,1078 \\
\hline 9 & 2,1290 & 1,9281 & 90,5653 \\
\hline 10 & 2,5887 & 5,8913 & 227,5775 \\
\hline 11 & 2,5887 & 1,6611 & 64,1673 \\
\hline 12 & 1,0544 & 2,1658 & 205,4059 \\
\hline 13 & 1,0544 & 1,3748 & 130,3869 \\
\hline 14 & 2,9422 & 4,0783 & 138,6140 \\
\hline
\end{tabular}


Tabel 3. Besar tegangan lentur di sekitar bukaan dari tiap kasus (Lanjutan)

\begin{tabular}{cccc}
\hline No Kasus & Tanpa bukaan & $\begin{array}{c}\text { Dengan } \\
\text { Bukaan }\end{array}$ & $\begin{array}{c}\text { \%Perbandingan dengan tanpa } \\
\text { bukaan }\end{array}$ \\
\hline 15 & 2,9422 & 3,1768 & 107,9736 \\
\hline 16 & 6,6924 & 11,5419 & 172,4628 \\
\hline 17 & 6,6924 & 7,0984 & 106,0666 \\
\hline 18 & 2,2325 & 3,7543 & 168,1657 \\
\hline 19 & 2,2325 & 2,8376 & 127,1041 \\
\hline 21 & 2,8256 & 6,8757 & 243,3359 \\
\hline
\end{tabular}

Pada grafik dibawah ini ditunjukkan perbandingan besarnya tegangan lentur di sekitar bukaan ketika bukaan berada di tengah pelat pada 3 kondisi, dimana kondisi 1 tanpa adanya bukaan, kondisi 2 dengan bukaan dan tanpa penggunaan stiffening ribs, dan kondisi 3 dengan bukaan dan dengan penggunaan stiffening ribs.

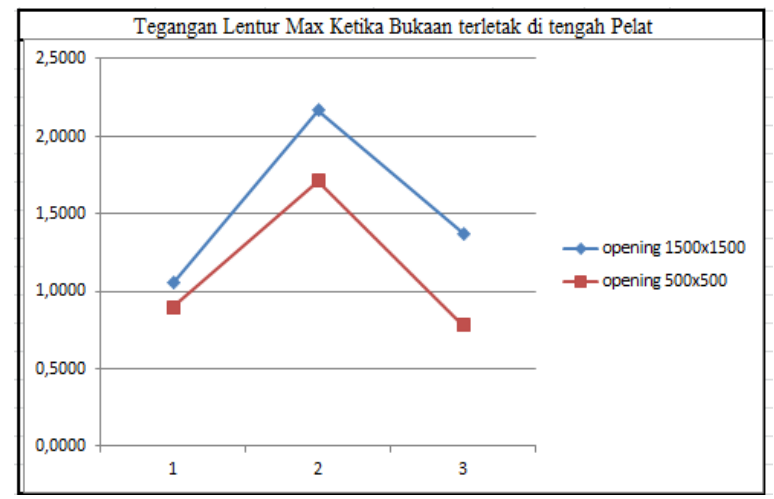

Gambar 6. Perbandingan tegangan lentur ketika bukaan berada di tengah pelat.

Tabel dan grafik diatas menunjukkan bahwa ada terjadinya konsentrasi tegangan lentur di sekitar bukaan, besarnya konsentrasi tegangan lentur lebih besar ketika ukuran bukaan tersebut berukuran lebih besar, dan konsentrasi tegangan lentur paling besar ketika bukaan berada pada sudut pelat.

\section{Hasil Analisis Tegangan Geser Pons}

Hasil analisis besarnya rasio tegangan geser pons dan tegangan tahanan geser pons ketika bukaan berada di tengah ditampilkan pada grafik dibawah ini: 


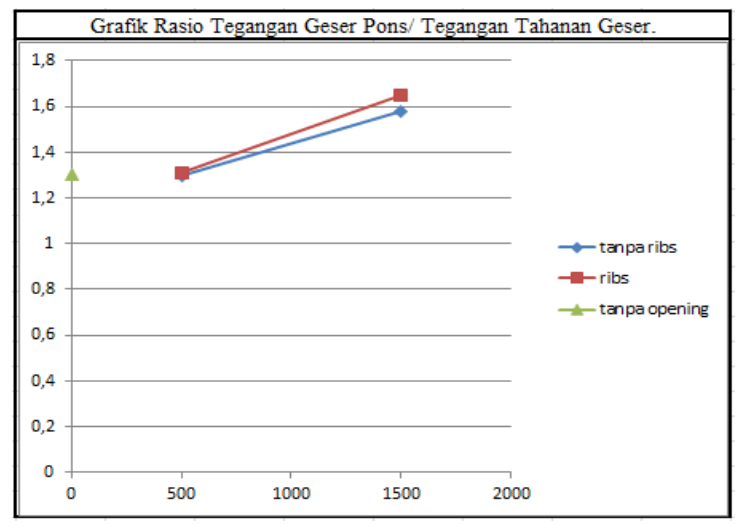

Gambar 7. Rasio Tegangan Geser Pons dan Tegangan Tahanan Geser ketika bukaan berada di tengah pelat

Grafik diatas menunjukkan bahwa adanya bukaan membuat besarnya rasio tegangan geser pons dan tegangan tahanan geser semakin besar, semakin besar ukuran bukaan membuat besarnya rasio tegangan geser pons dan tegangan tahanan geser semakin besar, dan penggunaan stiffening ribs membuat besarnya rasio tegangan geser pons dan tegangan tahanan geser semakin besar.

\section{Hasil Analisis Momen Lentur}

Hasil analisis besarnya momen lentur sisi bawah dan sisi atas ketika bukaan berada di tengah ditampilkan pada grafik dibawah ini:

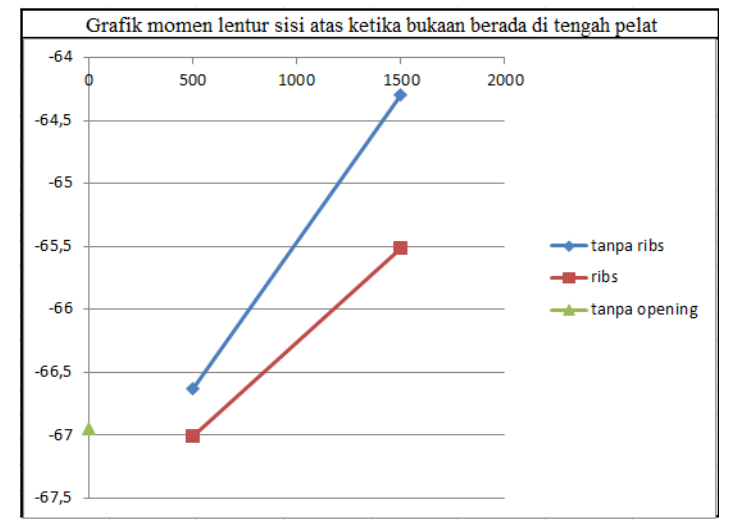

Gambar 8. Grafik momen lentur sisi atas ketika bukaan berada di tengah pelat.

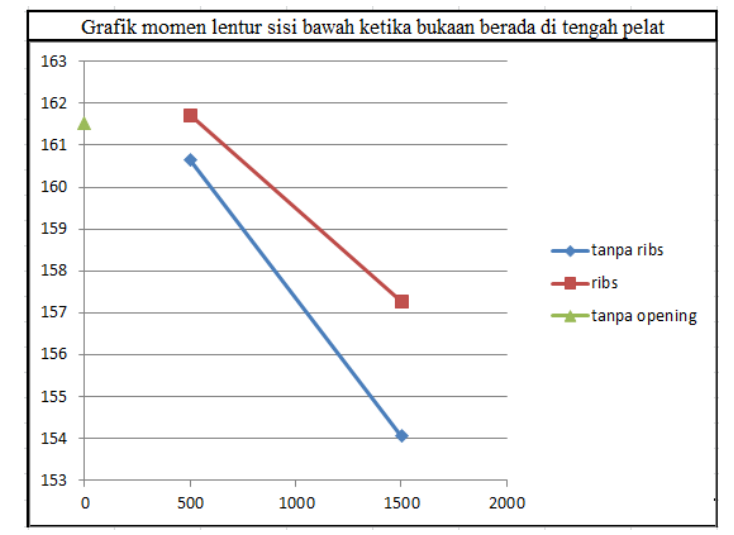

Gambar 9. Grafik momen lentur sisi bawah ketika bukaan berada di tengah pelat.

Grafik diatas menunjukkan bahwa adanya bukaan membuat besarnya momen lentur semakin kecil, semakin besar ukuran bukaan membuat besarnya momen lentur semakin kecil, dan penggunaan stiffening ribs membuat besarnya rasio tegangan geser pons dan tegangan tahanan geser semakin besar. 


\section{KESIMPULAN}

Berdasarkan hasil analisis dari studi kasus diambil beberapa kesimpulan sebagai berikut:

1. Terjadinya peningkatan konsentrasi tegangan lentur di sekitar bukaan yang mencapai lebih dari dua kali lipat dibandingkan tegangan lentur sebelum adanya bukaan.

2. Penggunaan stiffening ribs di sekitar bukaan memberikan pengaruh yang sangat signifikan terhadap berkurangnya konsentrasi tegangan lentur yang terjadi di sekitar bukaan dan besarnya lendutan yang terjadi pada pelat.

3. Bukaan yang diletakkan pada bagian sudut waffle slab memberikan konsentrasi tegangan lentur paling besar, lendutan paling besar, momen lentur yang paling besar, dan tegangan geser pons paling besar.

4. Ukuran bukaan pada waffle slab berbanding lurus dengan besarnya tegangan lentur, lendutan, dan tegangan geser pons yang terjadi pada waffle slab.

\section{DAFTAR PUSTAKA}

Choiron, A dan Purnowidodo Anindito, Dr.Eng. (2014). Modul Ajar Metode Elemen Hingga. Malang: Universitas Brawijaya

Isworo, S.pd,. M.T., Razi Pathur Ansyah. (2018). Metode Elemen Hingga. Kalimantan selatan: Universitas Lambung Mangkurat.

Puspantoro, M.sc, Ir.Ign.Benny. (1993).Teori \& Analisis Balok Grid. Yogyakarta: Andi Offset.

Rasheed Risna, P. Anima. (2017). "Effect of Spacing of Grid Beams and Opening Size in a Waffle Slab with Central Opening”. International Journal of Enigineering Research and General Science Volume 5, Issue 2.

Park, R. and Gamble, W.L. (1980) Reinforced Concrete Slabs (9th Ed.). Canada: John Wiley and Sons.

Singiresu S. RAO. (2004). The Finite Element Method in Engineering. Miami: Elsevier Science \& Technology Books.

SNI 2847-2013. Persyaratan beton struktural untuk bangunan gedung. Badan Standardisasi Nasional. Jakarta. 2013. Somasekhar Anjaly, Prabhakaran Preetha. (2016.). “Analytical Investigation on Performance of Stiffened Waffle Slabs with Openings”. IOSR Journal of Mechanical and Civil Engineering. e-ISSN:2278-1684.

Susanti, E., Youlanda, N. A., \& Winaya, A. (2016). Studi perbandingan pelat berusuk dua arah (waffle slab) dan pelat konvensional (On-Line). Jurnal IPTEK, 20(1), 25-36 
